\title{
CYBERNETIC MODELING OF TEACHER - STUDENT COMMUNICATION
}

\author{
Dariusz MECZYKOWSKI
}

Wojskowa Akademia Techniczna

\begin{abstract}
The research focuses on social system and general regularities (relations), typical and repetitive in them (among human beings as an exemplification of elementary objects). The main goal of the author is to indicate the possibility of modeling and optimizing the relationships (communication) teacher-student - or relationship coach-player - using the cybernetics research workshop. This epistemological-methodological convention results from the fact that system-cybernetic methods allow to describe and explain the phenomena under consideration in a different light, give them a new, wider meaning, draw conclusions that would often be impossible to derive from other sciences. Moreover, their utilitarian significance is expressed in the accuracy of formulating answers to the questions posed by practitioners. A significant result of the research process is also the determination of the conditions of sufficient and necessary efficiency and the effectiveness of communication between the objects indicated. They constitute general, typical and repeatable regularities. Therefore, ignoring them can only cause conflicts and social rebellions. In order to prevent them and maximize the effects of any training (information and energy), you must undoubtedly educate teachers and trainers in the field of sociocybernetics and psychocybernetics. The elements signaling and initiating such a process are contained in this text.
\end{abstract}

Keywords: Social cybernetics, Social communication, Information revolution.

\section{Introduction}

More and more often in scientific explorations, in the field of various areas of knowledge, an interdisciplinary approach can be found in the research process. The greatest value and strength of interdisciplinarity is the perception of common areas in science, once divided into areas, disciplines, departments, narrow specialties, and even individual problems. They realized in consequence that learning was one and one should approach problems comprehensively, distinguishing what is important for all science, regardless of its divisions. ${ }^{1}$ A new discipline of research that uses and acquires the achievements of various scientific disciplines, but does not fit into any of them, was named in the first half of the twentieth century - cybernetics. Cybernetics is a deductive science in the abstract axiomatic stage with significant qualities of universality (generality) and accuracy, and at the same time is logically and surely epistemologically simple (fulfills postulates of Popper's scheme). ${ }^{2}$ The object of her research is laws of control that are common to various

See more widely: M. Mazur, Historia naturalna polskiego naukowca, PIW, Warszawa 1970.

2 See more widely: J. Such, O uniwersalności praw nauki, Książka i Wiedza, Warszawa 1972. 
systems. Cybernetics is looking for and isolates the so-called isomorphisms (Greek izos - equal, identical, morfe - form, image), which means in the literal sense, the same as "the same form" (independent from material and content in general) and homomorphisms (Greek homoios - similar, morfe - form, image), means "a similar form". Therefore, the use of the cybernetics workshop for exploration in social sciences allows the rational determination of general, typical and repetitive truths (nomothetic explanation). At the same time, this approach contradicts the statement that is currently being promoted, that social sciences can only describe and classify the phenomena they recognize.

The importance of cybernetics is expressed in the application of its research apparatus to explore various systems in a general and unified manner (compact). The indicated feature of the control science allows to examine and transfer solutions and regularities detected in the examined system to other systems (Table 1). Cybernetics will enable the classification of systems and their testing, taking as a criterion, for example, the type of energy and matter, the degree of organization, the purpose of control. Such an approach is possible thanks to duality, which is based on one hand on the integrated whole, and on the other on decomposed parts. In addition, the interpenetration of different varieties of cybernetics creates the conditions for seeking relationships between, at first sight, distant scientific disciplines (for example natural sciences and social sciences). ${ }^{3}$

Table 1. System-cybernetic approach in different fields of study

\begin{tabular}{|c|c|c|c|c|c|}
\hline $\begin{array}{c}\text { Scientific } \\
\text { discipline }\end{array}$ & Physics & Biology & Economy & Linguistics & Cybernetics \\
\hline $\begin{array}{l}1-\text { energy } \\
\text {-financial } \\
\text { approach } \\
2-\text { informa- } \\
\text { tion -control } \\
\text { approach }\end{array}$ & 1
\end{tabular}

Source: own elaboration based on: R. Kozioł, W.R. Dąbrowski, Cybernetyka dla stuchaczy Akademii Wychowania Fizycznego, Kraków 2002, p. 20

3 R. Kozioł, W.R. Dąbrowski, Cybernetyka dla stuchaczy Akademii Wychowania Fizycznego, Kraków 2002, p. 20. 
Cybernetics because of its interdisciplinary values is a science that successfully permeates various fields of science and social life. Therefore, it can not pass the areas of education, upbringing and underlying them, the processes of communication and the ties between people, and nowadays the scientific and informational revolution, as well as the bonds between man and machine (device). On the other hand, the processes of communication (exchange of information) are the core of the processes of all teaching (conditioning, programming). The perception of such significant dependencies in the synthetically outlined research problem makes it legitimate to consider it fully legitimate and interesting not only in epistemological but also valuable in praxeological terms.

The main purpose of this exploration is to indicate the possibility of modeling and optimizing the teacher-student(relatively different system pairs) relationship (communication) with the use of a social cybernetics research workshop.

The main research problem is expressed in the question: what are the important methodological and praxeological values of the social cybernetics research workshop in the context of the study (cognitive and practical aspect) of communication between the teacher and the student (or trainer and player).

The main hypothesis is the following: the use of a cybernetics research workshop to study communication between a teacher and a student, allows precise description of phenomena and objectively existing regularities, as well as formulation of praxeological directives that are necessary to optimize information exchange processes.

In the research process, the strategies of the theory before the research and consequent deductive reasoning were used for certain reasons (premises constitute the theses of the theory). These theories include: the theory of autonomous systems, general information theory, theory of relatively isolated systems, cybernetic theory of characters, as well as axiomatic theory of cognition. ${ }^{4}$ I will also apply statements and derivative concepts derived in accordance with the rules of defining and reasoning theory.

\section{The essence of the scientific and informational revolution}

At the basis of momentous social changes there is always a process marked by rapid changes in the field of science, technology, in the aspect of production and the speed of transmission and the meaning of information in the whole social life. ${ }^{5}$ Changes of this nature can be called a revolution. Meanwhile, the revolution, the effects of which we observe now, began after the Second World War and was directly

4 The indicated theories are the foundation of Polish cybernetics school, whose precursor and greatest thinker was Marian Mazur.

5 See more widely: M. Mazur, Historia naturalna polskiego naukowca, PIW, Warszawa 1970, p. 5-13. 
related to the explosion of interdisciplinary science such as cybernetics, theory of regulation, information theory, game theory, system theory, decision theory, optimization theory, operation theory, theory of operational activities (praxeology).

Three basic features can be distinguished, which allow to extract the essence of the discussed phenomenon. The first feature concerns the acceleration of technical progress. New inventions are appearing and the time from their implementation to practical implementation in economy and technology is significantly shortened. The second feature indicates a source of technical progress, which should be found nowadays mainly in scientific research, and not only in practical investigations and searching for technicians. There is a process of releasing technical progress and a greater conditioning of it from science and its level. An important feature of the current scientific and information revolution is the special direction of changes in the technical, educational, economic and cultural aspects of social life. What is changing fundamentally is the nature of the material mass processed by the systems of this era, from the energy used by the mechanisms, towards machines transforming information, for example computers. ${ }^{6}$
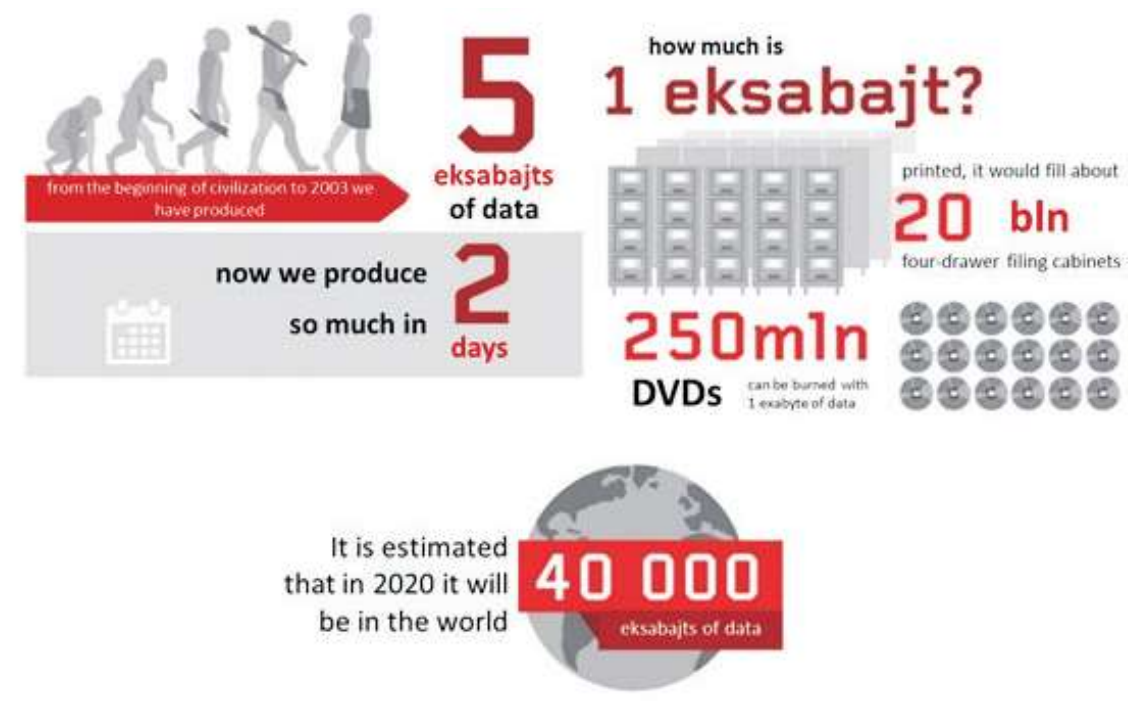

Fig. 1. The amount of data produced by mankind

Source: own elaboration based on: https://www.pablik.pl/36367/ile-danych-dziennie-produkujeludzkosc-obecnie-25-eksabajta-dziennie [28.07.2018]

$6 \quad$ S. Kurowski, Struktura społeczna a rewolucja naukowo-informatyczna (teoria kratyzmu), Wydawnictwo im. Konstytucji 3 Maja, Warszawa 1981, p. 2-3. 
Simultaneously with the scientific revolution, the stream of information is also growing (Fig. 1). To understand how large the modern information flood is, it is enough to realize that from the beginning of mankind until 2003, 5 exabytes of data were produced, where now it produces so much in 2 days. The estimates also indicate that in 2020 there will be 40,000 exabytes of data in the world, and there would be 5,200 gigabytes per person in the entire human population. ${ }^{7}$ During this revolution, there is an avalanche process of expanding the resources of social knowledge, which currently exceeds individual possibilities of accumulation and processing. On the other hand, there is a gradual anesthesia of people on information that is important (useful for steering) and assimilation of so-called information garbage. ${ }^{8}$ Such a phenomenon can be compared to the DoS or DDoS attack known in ICT networks, which consists in taking all free resources to refuse a service. In the case of people, their information channels are simply silted, so that as a result of indifference they lose their orientation in the actual social processes and directions of their changes. At the same time, access to knowledge is limited, which allows a qualitative analysis of information.

Contemporary trends in the development of the information society, which is the product of this scientific and informational revolution, lead simultaneously to changes in the formation of an individual man and the means and methods of socialization processes, that is adapting the human psyche to the requirements of a collective life. This is a particularly important social mechanism, because society can function as an autonomous super-system only when the conjunction of sub-programs of members of society and the supplement of society as an autonomous control process is not diminished. In the case of a weakening of conjunctions in society, chaos and disorganization (the process of backward adjustment) are successively progressing.

In other words, society continues when it can achieve its own goals, and at the same time every member of society is able to achieve personal goals. ${ }^{9}$ Therefore, efficient communication is a condition for building relationships on the interpersonal level. Proper definition and understanding of own needs and needs of the other side of the coupling give opportunities for cooperation and avoiding destruction. This is an important statement, also because we currently exist in a dense social environment understood as mutual and close connection of people with various technological means of emotional-information, as well as power relations. In such

7 www.lenovoblog.pl 1 eksabajt (EB)-10 ${ }^{18}$ can record 250 million dvd discs, printed they would fill about 20 billion 4-drawer document cabinets.

8 It is worth noting that despite the enormous development of science, mythical and stereotypical thinking still functions and still is doing well. What is also disturbing is the process of relapse of irrationalism, which may be the result of the ack of popularization and understanding of the achievements of science by the public.

9 J. Kossecki, Cybernetyczna analiza systemów i procesów społecznych, WZiA, Kielce 1996, p. 102. 
space there is a high degree of organization, but also a large dependence on people who cause inability to meet their needs, without the participation of people from outside the family circle.

The scientific-information revolution causes transformation of our society into a society rich in information - otherwise an information society. At the same time, it generates immeasurable opportunities for its members, including free access to knowledge, entertainment and other necessary resources and factors ensuring persistence and survival, but also stimulating positive development (improvement). In such a system, the information society allows people to become self-actualizing individuals, whose systemic autonomy increases and is realized simultaneously with a sense of security and happiness. For knowing and understanding the source of human knowledge and motivation and the regularity of the natural world has a key influence on finding the sense and purpose of individual and collective existence (Aristotle's purposeful cause). ${ }^{10}$

Range of stimuli stimulating the realization of new societies increases proportionally to the development of information useful in control processes. However, it is clear that such a potential opportunity presents huge problems and challenges to people in the field of science, education and upbringing (generally social processes of information production). Proper determination and resolution is essential before effective use of new resources becomes possible. Existence of a real threat that these chances and opportunities will be destroyed and society will be on the so-called dog's pursuit curve - there will be a regressive dynamic process or in the best case stagnation. Le Bon, in the famous now "Psychologia tłumu" (fr. La psychologie des foules, eng. crowd psychology) diagnoses this dependency, writing that good education is the greatest power a nation can gain; bad education is a voluntary poison embedded in the womb of one's own nation. ${ }^{11}$ For these reasons, education must be optimized on the basis of solid science, which detects the permanent regularities of social reality.

\section{Man as an exemplification of the autonomous system}

At the beginning let us assume that man is an exemplification of a simple system (a set of elements and relations) has inputs and outputs. Thanks to the entrances, the environment influences the system, and thanks to the outputs, the system interacts with the surroundings (Figure 2).

10 See more widely: J. Świniarski, Filozoficzne podstawy edukacji dla bezpieczeństwa, MON, Warszawa 1999, p. 40-42.

11 G. Le Bon, Psychologia tłumu, ANTYK, Kęty 2004, p. 47. 
Considering the relations of any system with its surroundings, it can be isolated (Figure 2) ${ }^{12}$ :

1. stimulus (S) - which is the influence of the environment on the system;

2. reaction $(\mathrm{R})$ - which is the effect of the system on the environment.

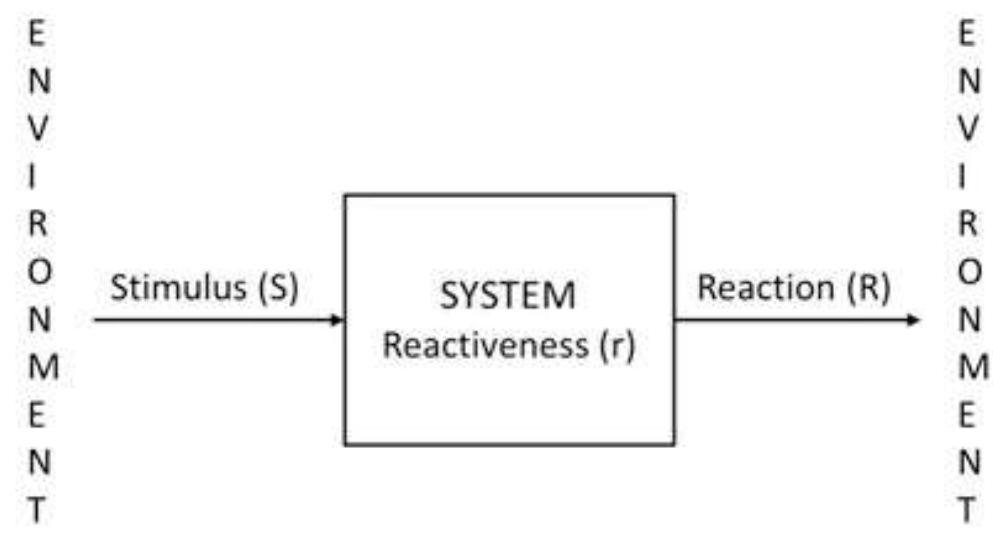

Fig. 2. Relationships of any system with the environment

Source: own elaboration based on: J. Kossecki, Elementy nowoczesnej wiedzy o sterowaniu ludźmi, WZiA, Kielce 2001, p. 20

The parameter describing the relationship between the system and the environment is the reactivity of $r$. In other words, it is a volume describing the ratio of the system's reaction to the stimuli acting on it. In the form of a pattern ${ }^{13}$ :

$$
r=\frac{R}{S}
$$

After transforming the formula (multiplying by $S$ ), it can be concluded that the behavior of any system depends on the influence of environment $B$ and its own reactivity $r^{14}$ :

$$
R=S \cdot r .
$$

From the above formula it follows that the causes of human behavior are two: he himself (or more precisely his reactivity) and the influence of the environment. The indicated court is one of ten claims about feedback. ${ }^{15}$

J. Kossecki, Elementy nowoczesnej wiedzy o sterowaniu ludźmi, WZiA, Kielce 2001, p. 19.

13 Ibidem.

14 Ibidem, p. 20.

15 M. Mazur, Cybernetyka i charakter, PIW, Warszawa 1976, p. 66. 
A second cybernetic principle of duality is taken as a certainty ${ }^{16}$, which distinguishes between the information and energy track (information entries and outputs as well as energy inputs and outputs). Hence, the system's reaction arises as a result of the information process and the energy process. In other words, there is a process in the information track that calls for a specific reaction from a number of possible reactions, while in the energy path there must be enough energy to trigger the reaction. The presented distinction between the information track and the energy track is "(...) purely theoretical, because it is impossible to implement separate tracks for transferring only information (without energy) and for transferring only energy (without structure, and thus without information). However, it is practically possible to implement an information track, which carries a large amount of information with a small amount of energy (control energy), and an energy track that transfers a large amount of energy (executive energy) with a small amount of information" (trans.). ${ }^{17}$ In the present times of the information revolution, where information becomes a material massively processed by the machines of this era, it seeks to reduce the amount of energy needed to transfer information. The key issue is knowledge, which gives the basis for a qualitative analysis of information and, consequently, access to power sources.

In connection with the above distinctions one can distinguish four main human needs ${ }^{18}$ :

1. Downloading information,

2. Issuing information,

3. Energy consumption (power supply),

4. Issuing energy (power supply).

While the need to collect and spend energy (power) is known by the concept of energy metabolism, the need to collect and release information, i.e. information metabolism, seems to be well-known to a lesser extent. The correctness of information processing has been described and explained by Polish psychiatrist Antoni Kępiński. He pointed out that: "Thanks to the «mine» information metabolism, not only does it become its own system, but also the surrounding world, which perceives itself in a specific way, experiences and responds to it in a specific way. As phylogenetic development of the nervous system, information metabolism plays an increasingly important role compared to energy metabolism (...)" (trans.). ${ }^{19}$

H. Greniewski, Cybernetyka niematematyczna, PWN, Warszawa 1969, p. 203-250.

7 M. Mazur, Cybernetyczna teoria układów samodzielnych, PWN, Warszawa 1966, p. 51.

18 Idem, Homeostaza społeczna, [in:] Procesy samoregulacji w oświacie. Problemy homeostazy społecznej, M. Pęcherski, J. Tudrej (ed.), PWN, Warszawa 1983, p. 107-115.

19 A. Kępiński, Psychopatologia władzy, [in:] Refleksje oświęcimskie, „Przegląd Lekarski” (nr 1/1967) rok XXIII, seria II, p. 52. 
The explanation of human needs as a system also results from certain sociotechnical methods of subjugating people ${ }^{20}$ :

- limiting the message (downloading information),

- limiting statements and decisions (issuing information),

- reduction of consumption (energy consumption),

- limitation of activity (issuing energy),

$\mathrm{Or}^{21}$ :

- forcing unwanted messages,

- forcing unwanted statements and decisions,

- forcing unwanted consumption,

- forcing unwanted activity.

The first four of these measures people feel as a violation of their freedom, the second as a violation of their dignity. ${ }^{22}$

The human body performs the functions of a simple system, i.e. there is an impact on the environment - issuing information and energy, as well as retrieving information and energy from the environment, processing and storing it. The indicated processes take place in the information track and the energy path of the system, which is different (from other systems), that it can persist in variables despite disturbances. Only the autonomous system manifests this ability, thanks to the organ called the homeostate. It prevents information and energy flows that reduce the system's ability to affect the environment (too large and too small flows). However, all plastic changes are more or less irreversible, hence the functional balance of the system changes despite the influence of the homeostate. ${ }^{23}$ "Therefore, the homeostate task can be more accurately defined as maintaining changes in the system parameters to the extent that the irreversibility of the transformations of the material is the smallest. Because the irreversibility of transformations of the material can not be avoided, so the existence of the independent system will be a continuous transition to more and more other states of functional balance, until the autonomous system fails to maintain functional balance and disorganization.

20 M. Mazur, Homeostaza społeczna, [w:] Procesy samoregulacji w oświacie. Problemy homeostazy społecznej, M. Pęcherski, J. Tudrej (ed.), PWN, Warszawa 1983, p. 107-115.

21 Ibidem.

22 Ibidem.

23 Równowaga funkcjonalna to stan, w którym wielkości fizyczne w systemie autonomicznym mają wartości najkorzystniejsze, tj. najbardziej odległe od wartości zbyt małych i zbyt dużych z punktu widzenia zdolności systemu autonomicznego do sterowania się, tj. mogących spowodować zniszczenie systemu. (eng. Functional balance is a state in which the physical quantities in the autonomous system have the most favorable values, i.e. the most distant from the values too small and too large from the point of view of the autonomous system's ability to control itself, i.e. that may cause the destruction of the system.) M. Mazur, Cybernetyczna teoria układów samodzielnych, PWN, Warszawa 1966, p. 57. 
The task of the homeostate is to delay this process as much as possible" (trans.) $)^{24}$, stabilize and defend against disorganization, "decay" and "disappearance".

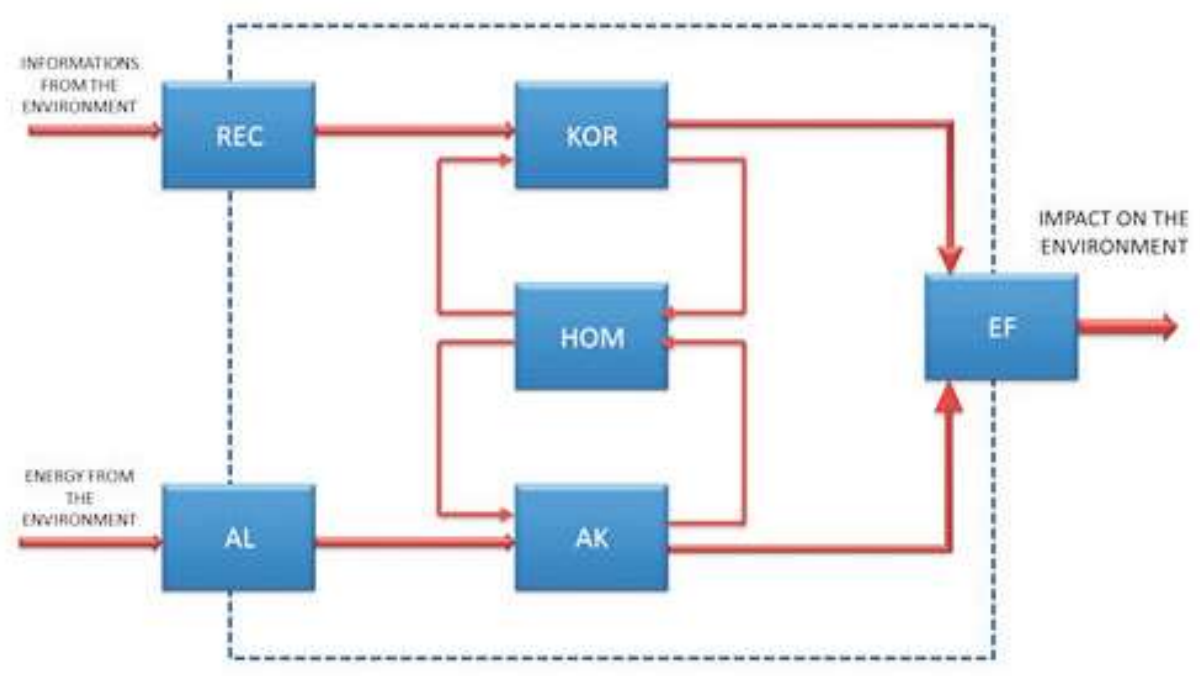

Fig. 3. Autonomous System

Source: own elaboration based on: M. Mazur, Cybernetyka i charakter, PIW, Warszawa 1976, p. 164

The autonomous system, in order to control itself in its own interest, must contain the appropriate organs, which are subsystems (Figure 3). We distinguish such organs as ${ }^{25}$ :

1. effectors [Ef] - organs for influencing the surroundings,

2. receptors $[\mathrm{Rec}]$ - organs for retrieving information from the environment,

3. correlator [Kor] - an authority for processing and storing information,

4. alimiators [Al] - organs for collecting energy from the environment,

5. battery [Ak] - an authority for processing and storing energy, and

6. hom eostat [Hom] - an authority to counteract information and energy flows that reduce the ability of the system to affect the environment.

The subsystems indicated in the diagram should not be considered in relation to, for example, man as structural elements, but as functional elements (we ask how it works and not how it looks?).

24 Ibidem, p. 106.

25 M. Mazur, Cybernetyka i charakter, PIW, Warszawa 1976, p. 120-128. 
Considering a human being as a special case of an autonomous system, the following personality components are distinguished, which are either rigid or elastic properties, as well as control characteristics and non-control properties (Table 2).

Character is a set of rigid control properties (character parameters). According to the second cybernetic principle of duality, the division into energy and information parameters is introduced. The control properties concerning information processing are: correlator capacity (intelligence) - number of correlation elements, correlator registration (ability) - ratio of the unit conductivity increase to the correlative power inducing it, correlation preferentiality (talent) - distance between correlation elements. ${ }^{26}$

Table 2. Personality components

\begin{tabular}{|c|c|c|}
\hline Personality & Control parameters & Non control parameters \\
\hline Rigid parameters & Character & Temperament, eye color \\
\hline Flexible parameters & Memory & $\begin{array}{c}\text { Current appearance, physio- } \\
\text { gnomy }\end{array}$ \\
\hline
\end{tabular}

Source: own elaboration based on: M. Mazur, Cybernetyka i charakter, PIW, Warszawa 1976, p. 271-272

The control properties concerning energy conversion are: dynamism - the ratio of the expansion factor to the aging factor, tolerance - the difference between boundary dynamisms of the character dynamics, susceptibility - it is the difference between impassable dynamism and the nearest boundary dynamism of the dynamism of character. In contrast, the sum of tolerance and vulnerability is the width of character. ${ }^{27}$

Rigid control properties change with the passage of time (the second law of thermodynamics), dynamism from exodynamism towards endodynamism. Character width from low tolerance towards higher, higher susceptibility towards lower. The same happens with the information parameters, the skills and capacity weaken, and new talents appear with the passage of time. Therefore, the main theorem of this theory is the judgment that character is impossible to change (in the sense of any human action for this purpose), which does not mean that it does not change at all with the second law of thermodynamics.

From the above characteristics of the course and properties in the autonomous system, it follows that the images of current reality depend not only on the reality (objective) of reality, but on the state of the previous imaginations in the correlator. Therefore, to control the autonomous system, you need messages containing information about current facts and historical facts about changes in the system itself and

26 Ibidem, p. 281-282.

27 Ibidem, p. 289-379. 
its surroundings. However, in order to predict specific reactions of a given system to a given stimulus, you need to know not only its character (6 parameters), but also the image of the situation, the idea of decisions (state of memory) and performance parameters of the effector - temperament (vitality).

Necessary condition for proper communication at the teacher-student level (trainer-player) is first of all to diagnose individual properties on both sides of the coupling. It is not possible to decode any ranges of signals by the receiver, and this can happen effectively in the range of brevity and frequency.

The intellectual properties discussed, i.e. intelligence, skill and talent, are based on the correlator's independent properties. Therefore, individual combinations of the intellect can be distinguished for simplicity using the dichotomous scale: the "small" and "large" grades.

Table 3. Types of Intellect

\begin{tabular}{|c|c|c|c|}
\hline & Intelligence & Acuteness & Talent \\
\hline Limitation & Low & Low & Lack \\
\hline General intelligence & High & Small & Lack \\
\hline Good memory & Low & Large & Lack \\
\hline Ingenuity & Low & Low & talent \\
\hline Erudition & High & Large & Lack \\
\hline Laborious improvement & High & Low & talent \\
\hline Intuitive accuracy & Low & Large & talent \\
\hline Versatility & High & Large & talent \\
\hline
\end{tabular}

Source: own elaboration based on: M. Mazur, Cybernetics and character, PIW, Warszawa 1976, p. 282

Therefore, unified teaching creates situations that are in line with the level of character of students who are average intelligent, average and average talented. Modern teaching and training must take into account both the intellectual and energetic parameters of both the teacher and the student. An information society that is knowledge-based (intensive development) can not afford a waste of potential of its members, because it means backwardness and backwardness in a strategic perspective.

\section{A general model of sender-receiver communication}

In general information theory, messages are elementary objects of a given set, and the relations between them are the information (object, relation and set are the primary concepts of the theory). These may be messages in the form of physical, chemical or biological signals. The processing of originals (message sources) into 
images (message receiver) and vice versa is called communication. Informing, on the other hand, is the processing of information contained between elements of the set of originals into information contained between elements of a set of images. ${ }^{28}$ In this case, the codes determine the method of this processing (Figure 4).

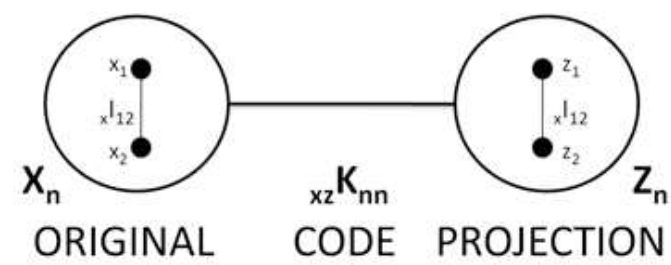

Fig. 4. Communication process Sender-Receiver (source-receiver)

Source: own elaboration based on: J. Kossecki, Metacybernetyka, NAI, Warszawa 2015, p. 33

Communication can occur between living and dead objects, i.e. they can be deterministic or probabilistic objects. The relationship between the two of those is dealt with by diagnostic and linguistic communication that takes place between living things, and such processes are considered by psychology, medicine or sociology and pedagogy (and other sciences). In these cases, the transmitter and receiver are people who exchange words with a specific channel (code). Specific messages are assigned to certain objects, relations, events. In order to understand it properly, people need to make an appointment about the meaning of messages and the relationship between them. This common set of characters with assigned relations is primarily a language for a human being.

Communication in the teaching process takes place simultaneously between the transmitter (teacher) and the receiver (student). In addition, the current recipient can become the sender of information. "Because the transmitter can simultaneously observe the receiver and draw conclusions about the understanding of the information transmitted by it, e.g. based on mimic changes and feedback, language communication is a feedback process or circular process, the stability of which is maintained by more such feedback processes)" (trans.). ${ }^{29}$

The main source of information in the teaching process should be an objectively existing event, i. e. an object, relation, phenomenon or process. In this process there are often distortions of information, which are a factor allowing to remove uncertainties about the momentary state of the event and lead to the enrichment of knowledge.

28 See more widely: M. Mazur, Jakościowa teoria informacji, WNT, Warszawa 1970.

29 G. Meyer, Cybernetyka a proces nauczania, thum. Cz. Kupisiewicz, PZWS, Warszawa 1969, p. 45. 
The teacher can be treated as a transmitter that receives information about a particular event and gains from it an image of $\mathrm{x} 1$, and then indirectly transmits the image to the receiver in the form of transformation into information y1. Further information transmission is made by means of various channels, e.g. physical signals or abstract symbols, sounds, language. The image of a given event is acquired by the teacher with the help of receptors such as eyes, ears, etc., and processed by the teacher in a coded form. An important element of efficient education is the use of codes understandable for the student, and also attractive cognitively (usually the air is the channel, but can also be sound, optical). Synthetically speaking, the teacher (transmitter) deals with acquiring, formulating (shaping) information and transforming it and transmitting it (Figure 5).

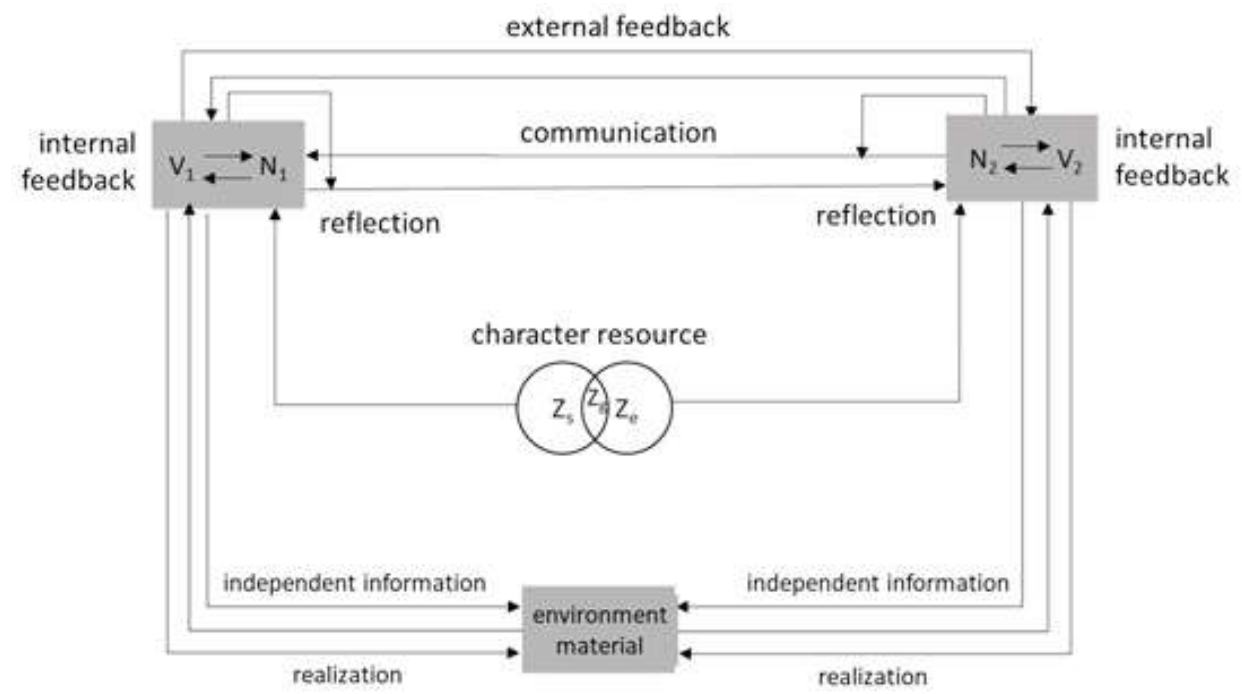

Fig. 5. Extended communication Scheme

Source: own elaboration based on: G. Meyer, Cybernetyka a proces nauczania, tłum. Cz. Kupisiewicz, PZWS, Warszawa 1969, p. 47

From the indicated model the following circular relations arise (feedback) ${ }^{30}$ :

1. Teacher-to-student communication using a language code.

2. Teacher-student feedback using non-verbal code, i.e. facial expressions both in the teacher and in the student.

3. Own external feedback circuit by means of a code in the form of reception by auditory receptors of own speech.

30 Ibidem, p. 48. 
4. Own internal feedback circuit using a code in the form of stimuli received by the muscles of the mouth.

5. Internal feedback circuit using code in the form of introspection and proprioreception.

6. Feedback circuit with a common set of signs (language).

7. New self-obtained information about the environment, which enriches its own range of signs and information.

8. System reactions, i. e. acting on the environment.

On the other hand, the student is a receiver of signals in the indicated model, which are the carrier of information provided by the teacher. The student must decode information $\mathrm{y} 2$, and convert the encoded information into a kind of $\mathrm{x} 2$ image for the receiver. The whole process begins by receiving through the receptors and transmitting signals to the correlator and involving feedback from the homeostate. Depending on the characteristics of the organs included in the information path, the receiver can react to individual information or the whole of its collection. It can also not receive certain information or do it at a characteristic rate. In principle, the processes in the information path depend on past and present ideas about the situation and ideas about decisions.

The ability to decode information depends on the section located in the window $H_{e} \cdot V_{e}$. The receiver can then decode the information only when its window section fits in its window. In the case when the flow of information in a unit of time is too fast $V_{e}$ the receiver will not be able to receive it, similarly will be in case of too condensed information $H_{e}$ (fig. 6).

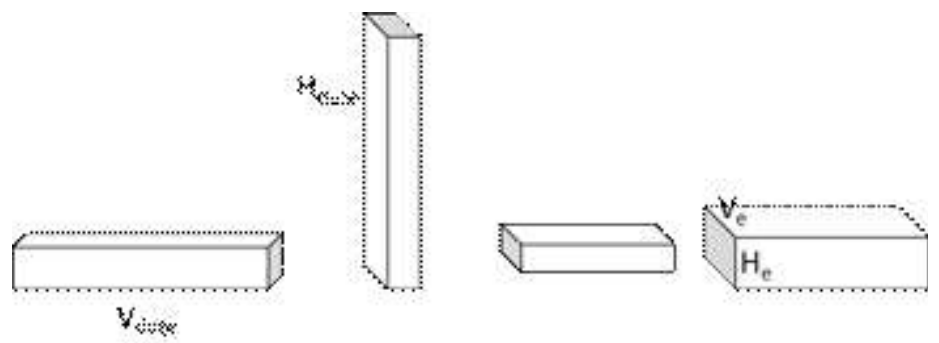

Fig. 6. Information and conditions of its receipt

Source: G. Meyer, Cybernetyka a proces nauczania, tłum. Cz. Kupisiewicz, PZWS, Warsaw, p. 39

If there are difficulties in receiving information and the information section is unmatched to the recipient's window, it must be transformed (i.e., recoded) to the requirements of the information path of the other coupling side. Depending on the recipient's control parameters, the sender must either soften the information, using redundancy to make it more available (for students with less capacity and higher 
capacity), or in the case of excessive frequency, the teacher must divide information and gradually develop logically (for pupils with less capacity and more knowledge). Everyone has individual abilities regarding information processing. Its capacity is limited and this applies both to information provided simultaneously and successively.

The concept of noise (or distortion, error) is directly related to the transmission of information and the communication process. They arise at every stage of the communication process, at the formation of a signal, in the course of its flow through the channel to the receiver, as well as during its decoding and reception. The noise distorts the original signal and consequently the information message. For example, a virus can sneak into an e-mail that distorts the content, or a copy of the document can be made in poor quality. In a verbal communication, we will not understand certain words. The teacher will be vaguely and quietly speaking during the lesson.

The necessary condition for optimizing the communication process (including the teacher-student) is to eliminate interference. And so, there are several forms of total or partial noise compensation. ${ }^{31}$

1. By repeating messages.

The single transmission of messages may generate errors that can be corrected by repeating the signals. Information between the messages sent several times becomes clearer and more understandable for the recipient than when it was sent once by the channel.

2. By changing the code.

Messages are coded into longer combinations and redundancy increases at the same time (it is better to say the Najwyższa Izba Kontroli (eng. Supreme Chamber of Control) instead of NIK). The transmitter uses additional, error-free codes and is understood by the other side of the coupling. It uses the association of signals into certain groups, eg. various underlining, emphasis, rhymes, colored markings, borders of patterns, giving clear examples and associations.

3. By changing the reception of information.

Instead of indirect information, entering direct information. If the previous reception of information took the form of a purely external (receptive) and mediated message, in this case the active method of analysis of the subject and information is used as the main method, eg the teacher instead of telling only about the laws of physics and applying the formulas may include experiments.

4. By using multiple channels.

Instead of just one channel, for example acoustic, others are used, acousto-optics, auditory, tactile, sensory, aroma and taste. The main goal is to activate the other receptors.

31 On the base of M. Mayer, Cybernetyka a proces nauczania, thum. Cz. Kupisiewicz, PZWS, Warsaw, p. 40-42. 
5. By enhancing the transmission power.

Strengthening the transmit power of the signal within the channel's limits can compensate for interference. Receipt of information can be improved qualitatively by strengthening the intensity of stimuli. However, it is not about the stronger influence of individual receptors, but rather the dynamics and change of stimuli. For example, a silent teacher can transmit information louder, which is not affected by the information capacity.

6. By binding new information to already owned ones

Linking new and fresh information provided by indicating relationships and relationships with information already acquired and developed (parainformation). The following techniques are used: analogies, associations, interpolations. Thanks to the combination and association of already existing information with new ones, the student gains new associations.

7. By a well-known code, consisting of easily distinguishable elements.

The information should be provided to the recipient using a well-known code that is clear and unambiguous. Thus, distortions of information are eliminated and confusion is not allowed. The code should contain symbols with the help of which it is possible to precisely capture information and exclude ambiguity.

8. Through a highly organized message structure

A highly structured information structure allows the recipient to properly understand them even in the event of serious disturbances. For example, if you remove one word from a sentence or one letter from a word, you can interpolate what has been omitted from the other elements. In this case, it is about reducing the entropy of information.

9. By checking the information received In the sender-receiver communication process, the functioning feedback enables the control by both sides whether the information is in the correct form and correctly coded and decoded. Thanks to such a construction, it is possible to correct and supplement information, which improves the efficiency of communication between the parties of feedback. In addition, individual couplings accumulate to form whole strings and coupling assemblies that provide as a result of a comprehensive cognition. Such accumulation allows to connect particular features and elements of cognition with each other.

Knowledge about regularities related to sender-receiver communication allows to identify sensitive and particularly addictive points. Such unquestionable knowledge is indispensable in order to optimize all teaching and training processes, because it allows to streamline the entire process and, consequently, to achieve the assumed goal of action. 


\section{Model of the teacher-student system (trainer-player)}

For exploration and modeling of the teaching and training process (in any field) you can use the praxeological chain of action, which is an ordered three of cells $s^{32}$ :

$$
£=\langle x, y, z\rangle
$$

where $x$ is the subject of action (perpetrator), $y$ is the intermediary of action, with the object of action (material). In graphical form, the action chain is shown in Figure 7.

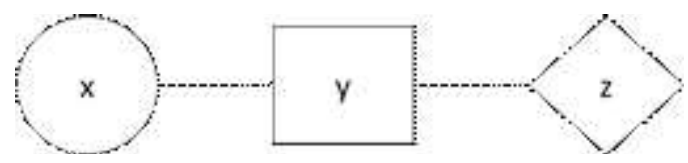

Fig. 7. Chain of Action

Source: J. Konieczny, Inżynieria systemów działania, WNT, Warszawa 1983, p. 63

At the same time, it is assumed that all intentional action is implemented in the chain of action and the subject of action in the chain can only be people and human teams. According to the adopted postulates, you can not operate outside the chain of operations, you can not replace all chain elements, e.g. with technical devices. For this reason, man always remains the subject (perpetrator) of his actions.

With the help of the introduced conceptual apparatus, you can identify all intentional actions of people and their teams. Objects and relationships in the chain can also be identified due to the type of material and character of the ties (Table 4). With the fact that we will not be interested in (according to the postulates) those chains in which the subject of action is the device (chains 5-8). However, for the correctness of inference, all combinations must be extracted.

Table 4. Distribution of ties (relationship) in ChainU action

\begin{tabular}{|c|c|c|}
\hline Criterion & Bond type (Relation) & Comments \\
\hline & 1) C-C - C & Bond man - man - man \\
& 2) C-C - U & Bond man - man-device \\
Between what & 3) C-U - $~$ & Bond man - device - device \\
real objects? & 4) C-U - C & Bond man - device - man \\
& 5) $\mathrm{U}-\mathrm{U}-\mathrm{U}$ & Bond device - device - device \\
& 6) $\mathrm{U}-\mathrm{U}-\mathrm{C}$ & Bond device - device - man \\
& 7) $\mathrm{U}-\mathrm{C}-\mathrm{C}$ & Bond device - man - man \\
& 8) $\mathrm{U}-\mathrm{C}-\mathrm{U}$ & Bond device - man - device \\
\hline
\end{tabular}

Source: own elaboration based on: J. Konieczny, Inżyniera systemów działania, WNT, Warszawa 1983, p. 43

32 Source: J. Konieczny, Inżynieria systemów działania, WNT, Warszawa 1983, p. 63. 
Chain No. 1 can be an example of a single man who is "himself a helm, a sailor and a ship" in action. Thinking (introspection) or individual learning can be such a special action. ${ }^{33}$

Chain No. 2 illustrates the situation in which the teacher asks to perform an exercise on a specific device, e.g. a computer, and the student acts as a mediator in this chain.

Chain No. 3 can be an example of a situation where a person uses, for example, a book to learn how to use a given computer or software.

Chain No. 4 presents the situation of so-called self-service, for example when a student uses a book to acquire information. An example of this chain can also be a student who uses a computer to work during classes.

The concept of the chain of action is useful in praxeological identification of various system situations (complex and elemental) and mutual relations between action chains. However, in the practice of teaching and training, all four of these types of action chains can be found. Combined relations (feedback usually) form whole sets of action chains that constitute complex systems of action.

The subsystem performing the control-regulating functions, for example, creates the following pairs (the subject and the intermediary jointly is the organizer): teacher-student, trainer-player, programmer-computer, student-book, doctor-patient, manager-employee. For this reason, the teacher-student hypervisor (or trainerplayer) can be presented and analyzed as a feedback process based on feedback (Figure 8). The subsystems of this superior system are, therefore, the sender of information (teacher, trainer), the recipient of information (student, player) and the communication channel with which messages are transmitted to each other. Thus, the teacher and pupil are influenced by the environment, and they also influence and change this environment.

The essential processes taking place in the teacher-student transceiver can be summarized in the form of the following algorithm. The teacher begins the implementation of the control process, gives the student at the first stage of education specific directives based on the goals they want to achieve, methods and means of implementation. During individual lessons, the student acquires knowledge and performs tasks provided in the curriculum (training), which defines the level of training, methods and means of training, control and measurement tests. At the same time, during the implementation of the program, the teacher measures the "quality" of these activities (or at least observations). The results of the measurement result in the assessment of the level of training, which constitute information useful in the entire learning (training) process. During teaching (training), work efficiency measurements are often carried out using various tests, the results of which are

33 Ibidem, p. 64. 
compared, for example, with the results of other students (players) representing a higher level of education or with standard results (assumed from above). ${ }^{34}$

The principal regularity regarding control is expressed in the statement that any flow of energy and information takes place from the higher potential to the lower one. Therefore, the teacher must have a higher level of character than his students. It can manifest itself e.g. in the information and teaching skills, or in access to large resources (wealth), and it can also be moral superiority. Depending on the method of the system of collective life (civilization), the higher potential is variously defined.

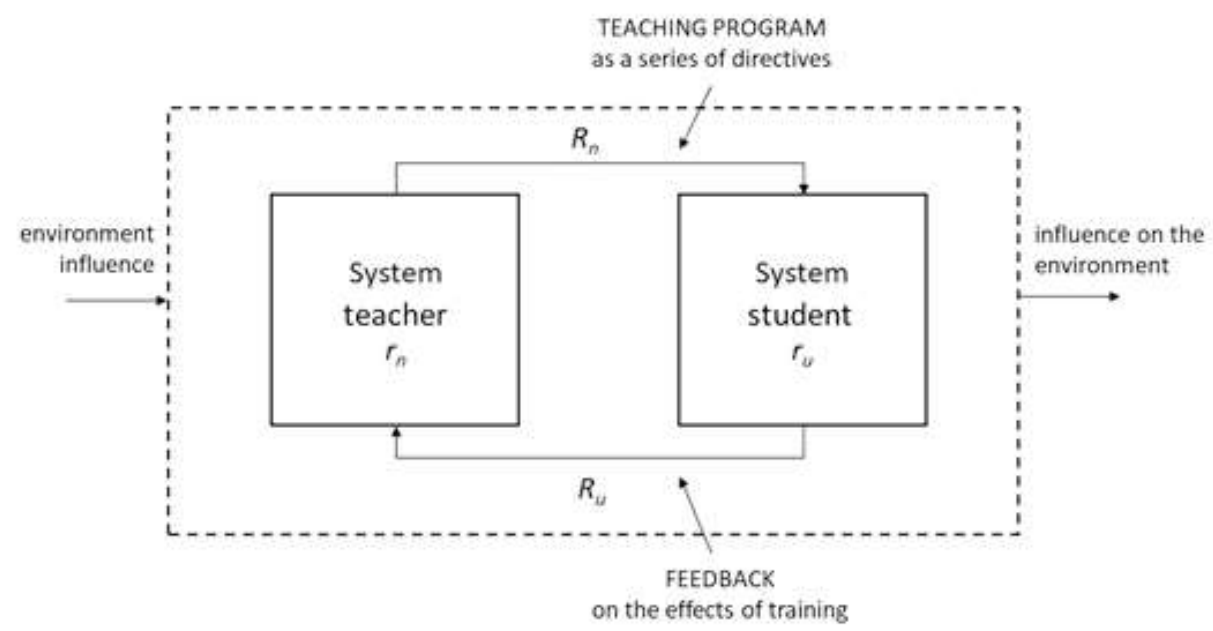

Fig. 8. Model of superior system teacher-student

Source: Own elaboration

In the absence of learning outcomes (training) in accordance with the principle of completeness, four causes of failure should be considered:

1. not such a curriculum (training),

2. not such a competitor (no predispositions),

3. no such measurement results (affected by error),

4. not this trainer (lack of competence).

In the appropriate selection of individual links of the indicated feedback, social cybernetics has a significant contribution. It allows to define both intellectual and energy parameters and, consequently, to support appropriate methods of impact and

34 By R. Kozioł, W.R. Dąbrowski, Cybernetyka dla stuchaczy Akademii Wychowania Fizycznego, Kraków 2002, p. 79. 
measurement of impact. While in sport the goal of the training seems to be clear and obvious (won during the competition), in education at every level, the goal of control is not precisely specified. The basic questions that arise during the development of educational programs concern the knowledge, skills and social competences that should be achieved by the student as a result of the education process. And here different interests clash depending on the environments that individual members of writing teams represent. The question then arises as to whether science provides tools for objectivization of such programs and for helping teams to create them. It seems that the elaborated text indicates a positive answer to this question. However, the need for wider dissemination of the achievements of modern science and the willingness to use them in the modeling and optimization of education.

The answer to the needs of education during the information revolution is undoubtedly the focus on algorithmization of teaching. Such an approach results from the information flood to which at present every human being is reporting. Therefore, it is more important to indicate the methods of qualitative analysis and use of information rather than the mere transmission (administration) of information. Teacher-student (trainer-player) must be aware of the mechanisms that communication and control processes in order to achieve success. There is no success without any effort, whether energy or information. People who are hardworking achieve success, because in accordance with the second law of thermodynamics, the mess is made by itself, and order requires spending energy!

\section{Conclusions}

The text shows the cognitive (theoretical) and praxeological (practical) significance of knowledge in the field of cybernetics, including psycho-cybernetics, sociocybernetics and information theory, for other areas of knowledge, especially communication and optimization of teaching (training) processes. The praxeological conclusion that follows from the text is as follows: the basis for improving the information-based (knowledge-based) teacher-student relationship (trainer-player) should be the achievements of modern science. However, the question arises about what science is going on? The answer is simple, because the conditions of the information revolution require a comprehensive (integrated) knowledge cognition. For these purposes, cybernetics was created more than seventy years ago. Contribution to the development of Polish scientists is greatly significant and useful.

While avoiding the unsaid and unjustified criticism, it should be noted that cybernetics does not negate the work and achievements of specialists from narrow monodisciplines. The point is that the discoveries should be coded in a language understandable to a wider audience. In addition, the use of the indicated research workshop may prove to be a conceptual apparatus enabling a broader and cumulative discourse covering various areas of knowledge and different points of view. 
Finally, it should be emphasized that ignoring the challenges that the information revolution generates before the societies will consequently lead asymptotically to the moods of dissatisfaction and unavoidable rebellion (there are limits to manipulation). It is a truism to say that prevention is better than cure. So let's prevent and inspire people to succeed! In this great ideological purpose, the text appears to be included in the conclusion.

\section{BIBLIOGRAPHY}

[1] Castells M., Społeczeństwo sieci, PWN, Warszawa 2010.

[2] Greniewski H., Cybernetyka niematematyczna, PWN, Warszawa 1969.

[3] Kepiński A., Psychopatologia władzy, [w:] Refleksje oświęcimskie, „Przegląd Lekarski” (nr 1/1967) rok XXIII, seria II.

[4] Konieczny J., Inżyniera systemów działania, WNT, Warszawa 1983.

[5] Kossecki J., Cybernetyczna analiza systemów i procesów społecznych, WZiA, Kielce 1996.

[6] Kossecki J., Elementy nowoczesnej wiedzy o sterowaniu ludźmi, WZiA, Kielce 2001.

[7] Kossecki J., Metacybernetyka, NAI, Warszawa 2015.

[8] Kozio£ R., DĄвrowski W.R., Cybernetyka dla słuchaczy Akademii Wychowania Fizycznego, Kraków 2002.

[9] KuRowski S., Struktura społeczna a rewolucja naukowo-informatyczna (teoria kratyzmu), Wydawnictwo im. Konstytucji 3 Maja, Warszawa 1981.

[10] Le Bon G., Psychologia tłumu, ANTYK, Kęty 2004.

[11] Mazur M., Cybernetyczna teoria układów samodzielnych, PWN, Warszawa 1966.

[12] Mazur M., Cybernetyka i charakter, PIW, Warszawa 1976.

[13] Mazur M., Historia naturalna polskiego naukowca, PIW, Warszawa 1970.

[14] Mazur M., Homeostaza społeczna, [w:] Procesy samoregulacji w oświacie. Problemy homeostazy społecznej, M. Pęcherski, J. Tudrej (ed.), PWN, Warszawa 1983.

[15] Meyer G., Cybernetyka a proces nauczania, tłum. Cz. Kupisiewicz, PZWS, Warszawa 1969.

[16] SUCH J., O uniwersalności praw nauki, Książka i Wiedza, Warszawa 1972.

[17] Świniarski J., Filozoficzne podstawy edukacji dla bezpieczeństwa, MON, Warszawa 1999.

[18] ZANIEwski Z.F., Zarządzanie zasobami ludzkimi w oświacie w perspektywie społeczeństwa wiedzy, Fundacja Studiów i Badań Edukacyjnych, Warszawa 2003.

[19] ZANIEWSKI Z.F., Human resource management in the education in the perspective of the knowledge society, Foundation for Studies and Educational Research, Warszawa 2003. 


\section{CYBERNETYCZNE MODELOWANIE KOMUNIKACJI} NAUCZYCIEL - STUDENT

Abstrakt. Badania składają się z systemów społecznych i ogólnych prawidłowości (relacji), typowych i powtarzalnych w nich (wśród ludzi jako przykład obiektów elementarnych). Głównym celem autora jest wskazanie możliwości modelowania i optymalizacji relacji (komunikacji) nauczyciel uczeń lub trener - zawodnik za pomocą warsztatu badań cybernetycznych. Ta epistemologiczno-metodologiczna konwencja wynika z faktu, że metody systemowo-cybernetyczne pozwalają opisywać i wyjaśniać rozpatrywane zjawiska w innym świetle, nadawać im nowe, szersze znaczenie, wyciągać wnioski, które często byłyby niemożliwe do wyprowadzenia $z$ innych nauk. Co więcej, ich utylitarne znaczenie wyraża się w dokładności formułowania odpowiedzi na pytania zadawane przez praktyków. Istotnym wynikiem procesu badawczego jest także określenie warunków wystarczającej i koniecznej efektywności oraz skuteczności komunikacji między wskazanymi obiektami. Stanowią one regularne, typowe i powtarzalne regularności. Dlatego ignorowanie ich może tylko powodować konflikty i bunty społeczne. Aby im zapobiec i zmaksymalizować efekty wszelkich szkoleń (informacji i energii), należy bez wątpienia kształcić nauczycieli i trenerów w dziedzinie socjocybernetyki i psychocybernetyki. Elementy sygnalizujące i inicjujące taki proces są zawarte w tym tekście.

Słowa kluczowe: cybernetyka społeczna, komunikacja społeczna, rewolucja informacyjna. 
